\title{
Different Approaches to Modern Art and Society: Li Zehou versus Xu Fuguan*
}

\author{
Téa SERNELJ
}

\begin{abstract}
Proceeding from the inseparable relation between ethics and aesthetics in traditional (and often also modern) Chinese thought, this article aims to illuminate two important approaches to the aesthetic foundations of Chinese modernity. The relation between the individual and society, which is a core question of modern ethics, is reflected in most of the ethical theories of 20 th century China. In this context, the article first presents Li Zehou's theory of aesthetics and his definition of aesthetic experience. In this way, it aims to illuminate Li's interpretation of modern art and society, and to posit it into a contrastive position to Xu Fuguan's ethico-aesthetic theories, especially the ones regarding modernity and Western culture. The basic approaches applied by these two important modern Chinese scholars reveal great differences in attitude towards the spiritual and material development of humanity in the 20th century, which is especially interesting since they are both rooted in the abovementioned belief that ethics cannot be separated from aesthetics. Besides, Li Zehou sincerely admired Xu Fuguan's work on traditional Chinese aesthetics and referred to his comprehension of general concepts of traditional Chinese aesthetics in many of his own works dealing with aesthetics.

However, on a deeper level, Li's approach is diametrically opposed to Xu Fuguan's understanding of the development of modern abstract art and society, since the latter exposes regressive and conservative tendencies in approaching modern Western art and society. This dissimilarity is of utmost importance and has wide reaching implications, for their particular aesthetic attitudes also clearly manifest themselves in their respective systems of ethical thought.
\end{abstract}

Keywords: Li Zehou, Xu Fuguan, sedimentation, aesthetic experience, modern art, Western art, abstract art

* The author acknowledges the financial support from the ARRS (Slovenian Research Agency; research core funding No. P6-0243 - Asian Languages and Cultures) and from the Chiang Chingkuo Foundation for International Scholarly Exchange in the framework of the research project Modern and Contemporary Taiwanese Philosophy 臺灣現代與當代哲學 (No. RG004-U-17).

** Téa SERNELJ, Assistant Professor, Faculty of Arts,

University of Ljubljana.

Email address: tea.sernelj@ff.uni-lj.si

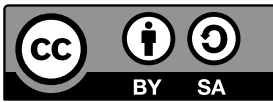




\section{Drugačni pristopi k moderni umetnosti in družbi: Li Zehou versus Xu Fuguan}

\section{Izvleček}

Izhajajoč iz neločljivega odnosa med etiko in estetiko $\mathrm{v}$ tradicionalni (in pogostokrat tudi moderni) kitajski misli pričujoči članek osvetljuje dva pomembna pristopa k obravnavi estetskih temeljev kitajske modernosti. Odnos med posameznikom in družbo kot osrednjim vprašanjem moderne etike je predmet razmisleka večine teorij estetike 20. stoletja na Kitajskem. V tem kontekstu članek najprej predstavi Li Zehoujevo teorijo estetike in njegovo definicijo estetskega doživetja. S tem osvetli Lijevo interpretacijo moderne umetnosti in družbe ter jo postavi v nasprotje etično-estetskih teorij Xu Fuguana, še zlasti teorije, ki obravnava modernost in zahodno kulturo. Osnovni pristopi teh dveh modernih kitajskih teoretikov razkrivajo velike razlike $\mathrm{v}$ odnosu do duhovnega in materialnega razvoja človeštva v 20. stoletju, ki pa je izjemno zanimiv zlasti zaradi že omenjenega prepričanja, da etike ne moremo ločevati od estetike. Li Zehou je odkrito cenil delo Xu Fuguana na področju tradicionalne kitajske estetike in se je v številnih svojih delih s področja estetike skliceval na njegovo razumevanje osrednjih konceptov tradicionalne kitajske estetike.

Toda na globlji ravni se Li Zehoujevo razumevanje razvoja moderne umetnosti in družbe diametralno razlikuje od Xu Fuguanovega razumevanja, saj zadnji pri obravnavi moderne zahodne umetnosti in družbe razkriva regresivne in konservativne tendence. Ta razlika je izjemno pomembna, saj se njuno estetsko dojemanje jasno kaže tudi v sistemih njunih teorij o etiki.

Ključne besede: Li Zehou, Xu Fuguan, sedimentacija, estetsko doživetje, moderna zahodna umetnost, abstraktna umetnost

\section{Introduction}

The thesis of the present article is that although Xu Fuguan had profound knowledge in Chinese traditional aesthetics and art, he failed to understand modernity as something mainly derived from the West, whereas Li Zehou has a much deeper, more complex understanding of the process. His works also reveal that compared to $\mathrm{Xu}$, he had a much more open attitude towards the development of art and society in China and the West. Although Xu was a member of the second generation of Modern Confucians who strove to build a bridge of understanding between China and the West, he failed to fully comprehend the main political, ethical and artistic agenda of modern Western art, because he generalized and misunderstood its fundamental characteristics, which led him to a misinterpretation of the socio-political background from which it emerged. Above all, he saw its development as a deformation and deviation of the function and the value of art in modern societies. $\mathrm{Li}$ Zehou, on the other hand, appreciated the aesthetic contents and the value of modern art precisely due to its being rooted in the specific historical development of Western societies, which he saw as an upgrading of aesthetic consciousness of 
human beings. Hence, in spite of the fact that Xu Fuguan doubtless belongs to the pioneers of aesthetics studies in modern China, and even though Li himself has never criticized Xu Fuguan's conservativism, I try to shed some light upon the reasons behind the fact that Li Zehou's attitude towards modern art and society is progressive, while Xu's position is conservative and traditionalist.

In order to understand Li Zehou's attitude towards the development of art and society, we will first briefly introduce his theory of aesthetics and the concept of aesthetic experience. This will help us to illuminate the basic paradigms of his theory of human development and his ethical theory, which are both reflected in his views on modern arts and their role in contemporary societies. In the second part of the article I will present Xu Fuguan's views on modern art and culture, and reveal some fundamental differences between the two divergent approaches applied by these two prominent theoreticians, working in the field of aesthetics.

As is already widely recognized, Li Zehou's work in this field is of utmost importance, for he is the first modern Chinese scholar, who created a coherent and complex theory of traditional and modern aesthetics. Xu Fuguan, on the other hand, belongs to the pioneers of modern Chinese aesthetic theory. Although Li has often shown a deep respect for Xu's work, their approaches to aesthetics and its role in human societies are quite different, especially regarding the perception of modern Western art and its role in the process of Chinese modernization.

\section{Li Zehou's Philosophical Aesthetics}

Li Zehou's theory of aesthetics is based on the synthesis of traditional Confucian and Daoist philosophy with Kantian and Marxists aesthetics. The mutually interconnected key concepts in Li's aesthetics are the humanization of nature (zirande renhua 自然的人化), the naturalization of humans (rende ziranhua 人的自然化), subjectality (zhutixing 主體性) and sedimentation (jidian 積殿). For Li, history is the result of human labour and sociality that reached its goal in the domain of aesthetics, which he understands as the unity of nature and freedom. Thus, in his view, aesthetics can help us to understand basic values and constitutions of human existence. Similar to the nature of traditional Chinese aesthetics, Li's theory is also based upon the presumption according to which aesthetics is inseparably connected with ethics. He often points out that Chinese aesthetics does not refer to anything religious, mystical or transcendent, but is instead based on the fusion of reason and emotion; hence, it rather refers to the basic questions of human existence, the universe, societies and interpersonal relations. He also reveals that Chinese philosophy and aesthetics have typically been guided by the pragmatism and practical rationality of daily life, by human relations, and by political concepts, rather than by any abstract and abstruse rationalist theory (Rošker 2006, 186). 
According to Li, pragmatism and rationality in Chinese culture can be traced back to the shamanist cultural tradition (wushi chuantong 巫史传统) of Shang and early Zhou dynasties. In shamanist tradition, human beings possessed the power to communicate among different realms of existence, including heaven and earth; they believed that human faculties and actions can influence and control these realms, and are therefore able to assume an active and determining role in the making of the world. In ancient China, the sages transformed and rationalized the power of shamans into external rites, which became rational guidelines for human behaviour, while music, dance and poetry became the emotional and poetic responses to the harmonies of the world ( $\mathrm{Li}$ and Cauvel 2006, 24). When this shift occurred, music and poetry became transformative arts because they had the power to transform a person in ways reminiscent of the powers of the shamans (ibid., 25). This shift in ancient Chinese society also resulted in the unified relation between heaven (or nature) and man (tianren heyi 天人合一). It was enacted in shamanistic rituals that were led by practical goals (such as praying for rain), and not as a quest for the salvation of the human soul. Heaven was not represented as an anthropomorphic god or deities, but was revealed to humans in the course of ritual performance (Chan 2003, 117). The pragmatic content of the ritual is also the reason why rituality was not perceived as mystical or somehow metaphysical.

The concept of humanization of nature (ziran de renhua), a term which Li adopted from Marx's Economic and Philosophic manuscripts of 1844 (1844), is based on his philosophy of anthropological ontology (renlei xue benti lun 人類學本體論), where everything that exists is connected with the existence of human beings and can be comprehended from a social and historical perspective rather than from the viewpoint of metaphysics ( $\mathrm{Li}$ and Cauvel 2006, 40). Therefore, Li's anthropological ontology focuses on social practice as the concrete process of the historical development of human beings as a whole (ibid.). The humanization of nature evolved through a productive practice of labour, which $\mathrm{Li}$ describes as the making and using of tools ${ }^{1}$ (gongju 工具), which manifested itself on two levels: The first level refers to the humanization of external nature, where humanity created material civilization. The second level refers to humanization of inner nature (senses, perception, feelings and desires), by which humanity created a spiritual civilization.

The main concept in this process is the practice of the so-called subjectality (zhutixing 主體性), which Li describes as the ability of culture to transform the natural world, and the inside and outside of the human world (ibid.), as well as the subjective human desire and the intention to understand the truth. All this was

1 The term was adopted from Georgi Plekhanov's aesthetics in which art as a form of social consciousness is subordinated to the mechanism of sociohistorical development where labour preceded and established beauty (Rošker 2019, 188). 
reflected in the human longing for goodness and the love of beauty (Rošker 2006, 182). The manifestation of subjectality on the objective level is reflected in technology and in social existence, whereas the subjective level of subjectality manifests itself through the process of production, which also contains the subjective level of social consciousness. This level manifests itself in culturally conditioned mental structures. Hence, for $\mathrm{Li}$, subjectality is not primarily the subjective awareness of an individual in the sense of sensations, feelings, desires etc., but rather refers to the results of human history that manifest themselves in deep structures of spiritual and intellectual culture, which also entail structures of ethical and aesthetic consciousness ( $\mathrm{Li} 2001,183)$.

For Li, human nature or the humaneness (renxing 人性) is a fusion of the social and rational, the biological and sensuous. It is the result of the coalescence of emotional life and rationality, the fusion of natural and social nature, which is a product of continuous evolution (Woei 1999, 106). This unification is achieved through the dynamic process of the humanization of nature, and thus through an interaction between human subjects and natural objects. In this process, sensitivity and naturalness are transformed by rationality and social factors (Rošker 2006, 183).

This transformation manifests itself in the sense of beauty (meigan 美感), which is the result of human social and productive practices. Li argues that the humanization of the external world reshapes the external world into beautiful objects and scenes, which thus become the source of beauty (Li and Cauvel 2006, 88). The humanization of the inner world forms aesthetic feelings in the subjective psyche, which is the origin of aesthetic experience or the sense of beauty. Thus, according to him, both processes are a result of the historical practice of human society.

\section{Aesthetic Experience as the Product of Sedimentation}

Li explains beauty in the framework of the Marxist conceptualization of humanized nature:

自然本身并不是美; 美的自然是社會化的結果, 也就是人的本質對象 化的結果. 自然的社會性是自然美的根源. (Li Zehou 2002, 184)

Nature as such is not beautiful. Beautiful nature is a result of socialized nature, i.e. a result of the objectification of human essence. The socialization of nature is therefore the basis of its beauty. 
For Li, the essence of beauty originated from humans' making and using of tools, while the aesthetic experience emerged from the feelings associated with successful labour. The shaping of tools, the shaping of environment, and the reciprocal shaping of human beings are, according to $\mathrm{Li}$, the original artistic activities, and the pleasure accompanying them is the earliest aesthetic experience $(\mathrm{Li}$ and Cauvel 2006, 5). The successful production of objects and the accompanying feeling of pleasure occur because of the correspondence between human beings and nature. Throughout the history of humankind, social and material practices have formed-and continue to form-innate human cultural-psychological formations through the process of sedimentation (ibid.).

In Li's theory, the concept of sedimentation is a historical process of accumulating human practical experiences which results in a fusion of the social and the individual, creating psychological and cultural formations of the human mind (Pohl 2015, 93). Human material production, with its psychological counterpart, leaks sediment into the human mind and is in fact an ongoing dynamic process within the cultural-psychological formation. In the human mind, sedimentation occurs on three levels (or sediments): species sedimentation, which includes forms common to all human beings; cultural sedimentation, which refers to the ways of thinking and feeling that are common to our own culture; and individual sedimentation, which is our individual life experience (Cauvel 1999, 158). These sedimentations are constantly in a dynamic process of change and interaction, and are by no means a priori categories of our mind (in Kant's sense), but rather represent a fusion of the social and the individual developed by society's historical evolution and material production.

Aesthetic sensibility is the most important human faculty, which through the process of psychological and cultural sedimentation transforms our comprehension of the world (Bruya 2003, 138). Nature became an object of aesthetic appreciation (or the aesthetic object) only after the process of the humanization of nature reached a certain level of historical development, when humans recognized the natural environment as a resource and instrument for their daily lives. Only then did the natural objects (mountains, rivers, clouds, rain, moon, etc.) begin to possess the essence of beauty and express aesthetic qualities ( $\mathrm{Li}$ and Cauvel 2006, 72).

The perception of beauty and the aesthetic sensibility have been embedded in our psychological-cultural sedimentation throughout the historical process of humanizing nature, whereby naturalization of human beings occurs as its counterpart.

The term naturalized humans, which Li developed from Daoist, especially Zhuangzian philosophy relates to three meanings: a) to nature as the environment for living; b) to nature as an object of appreciation and entertainment, and c) to the integration of humans and nature through specific practices (e.g. qigong, meditation, etc.), where they learn to adjust their body and mind to the rhythms of nature (ibid., 75). In Li Zehou's interpretation, the concept of the naturalization of 
humans thus appears as the corresponding element of the humanization of nature and functions as a process eliminating the alienation of human beings from nature.

According to $\mathrm{Li}$, the humanization of nature and the naturalization of humans are based upon the classical Chinese concept of the unity of Heaven and man (tianren heyi). For $\mathrm{Li}$, the specific spirit of Chinese aesthetics, which is based upon the complementarity of Confucianism and Daoism, can be found precisely in this unity. Hence, for Li Zehou, the theory of the unity of nature and man is simultaneously a theory of the transformation of men and nature, because it includes both the humanization of nature, as well as the naturalization of man. It aims to achieve human fulfilment or the wholeness of human nature.

The humanization of nature is represented in Confucian tradition as an emphasis on moral values and ethics, while the naturalization of humans is expressed in Daoist (especially in Zhuangzi's) philosophy, which emphasizes the value of personal freedom.

According to Li, Confucian humanization of nature is based upon the socialization and cultivation of human instinctive desires and needs, and the balancing and moulding of human emotions regarding interpersonal relations and morality. Daoist (especially Zhuangzi's) naturalization of humans is founded on withdrawal from human affairs and moral laws, uniting solely with the laws of nature. Zhuangzi's speculation on the art of life unwittingly created the highest aesthetic spirit that consequently made artistic activities possible. Zhuangzi's philosophy of wandering at ease (xiaoyao you 逍遥遊) is comprised of mastering the technique ( $g$ ongfu 功夫), the aesthetic perfection, and the freedom and liberalization of the human spirit to achieve unity with the Dao, which is the highest aesthetic experience.

Li's concept of sedimentation is the product of humanization of nature as well as naturalization of humans. It is expressed through the aesthetic awareness and creativity of particular historical periods. Sedimentation is the ongoing and dynamic process of human consciousness, and it forms the aesthetic experience of human beings. Li made a thorough historical and anthropological research in the psycho-emotional factors of aesthetic experience that forms the core of human aesthetic consciousness or awareness.

\section{Aesthetic Experience as a Pleasant Sense of Freedom}

Li Zehou defines aesthetic experience as the unity or the fusion of the rational and sensuous, and thus sensation, understanding, imagination and emotion. Aesthetic experience is the outcome of the process of humanizing inner nature, where human beings cultivate feelings, needs, desires, and sensory organs which 
consequently change their physiological nature. The humanization of inner nature takes place in the process of humanizing external nature, in which human beings transform the natural environment in accordance with their needs through labour, thereby transforming the objective relationship between themselves and the nature. Aesthetic experiences emerge from the process of sedimentation, which refers to the accumulation and deposits of the social, rational, and historical in the individual through the process of humanizing nature $(\mathrm{Li} \mathrm{2004,94).} \mathrm{In} \mathrm{this} \mathrm{way,}$ humanization of the external environment transforms the world into a realm of beautiful objects and scenes, which become the source of beauty. The humanization of the human inner world, on the other hand, forms the aesthetic feelings in the subjective psyche and is the source of aesthetic experience or the sense of beauty. Both processes have been evolving through the historical practice of human society ( $\mathrm{Li}$ and Cauvel 2006, 88).

For $\mathrm{Li}$, the aesthetic experience is sensuous as well as supra-sensuous because it is sensuous, intuitive, non-social and non-rational, but at the same time social and rational but disinterested. In defining the aesthetic experience, $\mathrm{Li}$ agrees with Kant's definition of it as the harmonious interaction of the free play of the imagination and understanding, but for Li, the weakness of Kant's definition lies in the overemphasis on the rational and in his reduction of aesthetic experience to a mere interplay between imagination and understanding. For $\mathrm{Li}$, it also includes aesthetic pleasure, which contains not only psychological, but also physiological factors (ibid. 107).

Classical art produces simpler aesthetic pleasure, while modern art feels unpleasant at first, but eventually it brings about a feeling of mental satisfaction in which pleasure arises from displeasure (ibid. 108).

The aesthetic experience or the sense of beauty of the external (natural) world, as well as of artworks, is in its essence a pleasant sense of freedom. How are these two, the aesthetic experience (or the sense of beauty) and the feeling of freedom, related? Li believes that human beings became familiar with the universal laws of the natural world through the human material practice of making and using tools. In the process of making and using tools productive labour utilized natural laws, which gradually acquired the form and the function of universal regularity. Step by step, people mastered various orders of nature and became familiar with different laws of form, which allowed them to imbue external things with aesthetic qualities. Because humans' material production brings about isomorphic structures $^{2}$, the properties of natural objects (growth, movement, development,

2 The sympathetic structural correspondence between the forms of nature and the structures of human mind/body, where the dynamics of external (physics) and inner worlds (psychology) exhibit similar principles due to their structural correspondence. 
etc.) and their forms (rhythm, symmetry, balance, harmony, order, simplicity, repetition, etc.) enter into the realm of beauty ( $\mathrm{Li}$ and Cauvel 2006, 56). For $\mathrm{Li}$, beauty originates from the activities of making and using tools, and appears in the earliest human practices of reshaping (or humanizing) nature (ibid.). $\mathrm{Li}$ asserts: "Freedom is the power to understand the universal (natural) forms or laws by overcoming natural necessity. With this power, the subject is free before any individual object." (ibid., 57)

Therefore, both in real life and in the practice of art, freedom means subjective practice acting objectively in accordance with objective universal laws. It enables the human subject to create beauty and to enter into the realm of beauty, and to intermingle his or her subjective purposes with the objective laws of nature in perfect harmony.

Freedom, which is the purpose of human beings, and the form of freedom, which is the root of beauty, are neither given by God nor exist naturally, nor are symbols of subjective ideas and emotions, but are objective powers and patterns of actions created by human beings through long historical practice. (ibid., 58)

However, $\mathrm{Li}$ argues that we must define freedom as the power to produce objective change. Freedom shapes objects in accordance with natural laws and, hence, it is a universal power for transforming things in the external world, as well as in the internal world of human beings.

Here we can see that, in the context of his anthropological ontology which is based on materialistic grounds, Li Zehou has to a certain degree upgraded Schiller's understanding of the relation between the aesthetic experience and freedom. Schiller argued that we experience beauty in those natural objects, the formation of which is based on rules. Therefore, the experience of beauty is rooted in the impression of regularity. Secondly, this rule must not be imposed on the object from the outside but rather stems from the object itself, which means that the object appears as self-determined, as self-regulated, as free. If both conditions are fulfilled, that is, if we perceive the object as following a rule imposed by itself, we experience it as beautiful. Since the experience of beauty implies freedom, beauty is nothing other than freedom in appearance. Human beings can hence experience freedom via their perception (Welsch 2006).

Schiller transfers the character of freedom from the human sphere into the natural world. In his idealistic aesthetics, freedom is already a natural phenomenon before becoming a part of human life. The difference between human beings and nature is not one between freedom and non-freedom, because both possess freedom. Hence, freedom is not a human privilege but rather a natural fact, and 
this is precisely what is discovered and embraced through human aesthetic experience (Welsch 2006).

This assertion was of extreme importance in Western aesthetics because it aimed to abolish a dualistic worldview in which human beings were perceived as being separated from nature. In contrast, Li's theory of the so-called "one-world view (yige shijie guan一個世界觀)”, which is based upon the general holistic worldview that prevailed in the Chinese intellectual history, emphasizes that humans are an inseparable part of nature, and therefore the dualistic view (mind/body, subject/object, etc.) is absent from the Chinese ideational tradition. And further, Schiller's assertion that beauty is objective because it possesses regularity or laws that correspond to human perception is an idealist one, because it neglects the productive engagement of human labour and views humans merely as passive recipients of some higher powers of nature.

Hence, Li's position of the relation between the aesthetic experience and freedom is different from Schiller's in the sense that for Li Zehou the aesthetic experience (or the sense of beauty) is the product of human material production, which enabled people to gain comprehension of natural laws, to humanize nature and consequently to develop aesthetic experience and the sense of freedom, which are both exclusively products of human faculties.

Aesthetic experience is inseparably connected to art, as it directly reveals human creativity as the capacity and manifestation of human freedom. Although aesthetic experience cannot be limited solely to the experience of artworks, it is nonetheless the most crucial factor in human engagement and development of the world of art. On the one hand, it is an expression of the human sensation of beauty and freedom, and on the other it represents the sublime fusion of the external and internal world in human daily life, which enables us to resonate with the world and pervades human life with deeper meaning.

\section{The Meaning of Art in Human Daily Life}

According to Li Zehou, an object becomes an artwork only when it appeals to a person's psycho-emotional construction, when it is able to rouse emotions merely through its formal structure and not through direct representation of emotional images ( $\mathrm{Li}$ and Cauvel 2006, 129). The power of formal structure acts on, influences and constitutes aesthetic psychological construction. In other words, objects become works of art when a person perceiving them has an aesthetic experience, which allows these objects to enter into his or her aesthetic awareness. However, according to $\mathrm{Li}$, the very definition of art should be left open because there are no rules for art to follow, since materials change and so 
do subjective experiences. An aesthetic object or an artwork is the manifestation and reflection of the states of mind of people living in different times and societies, as determined by specific socio-economic, political, and cultural conditions (Li and Cauvel 2006, 132).

$\mathrm{Li}$ asserts (ibid., 144) that art originated from witchcraft or developed along with it, while aesthetic experience originated from human labour. Witchcraft works to provide a tribal history (myths, legends) that can organize and mobilize people to preserve and hand down experiences of the past. Therefore, art was not created for the purpose of aesthetic experience. Still, although aesthetic experience does not primarily relate to art, it is inherently interwoven with it. If we understand aesthetic experience as our experience of the world where the inner world of human beings (which includes our emotions, understanding and senses) resonates and corresponds to the external world, and this fusion provides a profound feeling of beauty and freedom, it also gives us inspiration and contemplation that can be reflected and expressed not only in the sphere of artistic creativity or the arts, but also in our daily lives. As Li argues:

It is possible to have an aesthetic experience of a daily experience, and even of universal aesthetic experiences. These ideas are consistent with the tendency of modern, popular art to invade daily life. Because of the mundane quality of daily experience, which confines us to fixed spaces and times, we naturally wish to have our imagination and expectations satisfied in the illusory world of art. (ibid., 146)

The function of art in human lives provides us with possibilities to contemplate on our emotions, on our life potential, and on the world itself. Hence, art as well as the aesthetic experience are both expressions and manifestations of human creativity and freedom. As mentioned above, Li Zehou emphasized that through time and material development, the aesthetic experience becomes more complex and profound because it is endowed with increasingly deeper contents. The development of aesthetic experience continuously produces new sensations and understandings which bestow us with new sediments in our psycho-emotional structure. Li finds modern abstract art a great stimulus for the development and enrichment of aesthetic experience because it is, in contrast to classical art, saturated with increasingly multifaceted socio-political backgrounds. Hence, abstraction as a specific mode of artistic expression provides the human mind with more complex and sophisticated sediments. 


\section{Li Zehou's Aesthetic Understanding of Modern Art $^{3}$}

As mentioned above, $\mathrm{Li}$ argues that the aesthetic experience is more complex in modern abstract art than in the traditional representational art. According to him, abstract art is more powerful because it does not use concrete images to express deeper psycho-emotional structures and emphasizes the artist's reflection on the socio-political and economic conditions of the era. Classical representational art, such as the Chinese landscape painting, for example, uses more or less concrete images to provide the aesthetic experience of the beauty of the world and contemplation of human emotions, whereas modern abstract art negates classical forms, and deforms concrete images in order to evoke more complicated intellectual feelings. Although these images seem simple, their content is rational, or super-rational, and therefore more difficult to grasp ( $\mathrm{Li}$ and Cauvel 2006, 153). The fact that the works of the modernist school appear in an infinite variety of fantastic forms expands the meaning of art (ibid., 127).

Modern abstract art emerged as a response to the turbulent, grotesque, absurd and riotous world; it expressed feelings of alienation, terror and horror. In such a world, the presentation of beauty would be false, hence in modern art the representation of the ugly became the presentation of beauty. Although at first people feel discomfort with such artworks, it is precisely the emotional and intellectual content that consequently provides the satisfaction. As Li asserts,

Modern art is the isomorphic structure corresponding to the hearts of modern people. The spirit of revolt in abstract art expresses people's desire to escape from limitations and oppressions of the finite world and displays a colourful rainbow of liberation. (ibid., 154)

In other words, modern art appears to be abstract because what it expresses cannot be expressed by concrete images. For $\mathrm{Li}$, the abstraction presents something broader and more powerful. He argues:

Why does Picasso 4 employ fragmented, deformed images of ox heads, horse bodies, women, and children to show the suffering and death brought about by the fascists in the Spanish civil war, instead of painting

3 The term modern art refers to the artistic styles and philosophy of art that emerged in the end of 19 th century and lasted till the middle of the 1970s when postmodernism emerged. Modern art presents the abolition of features represented in traditional art, such as realistic depictions, narrative, etc. and engages in abstraction and experimentation. Modern art also includes avantgarde movements, such as fauvism, cubism, Dadaism, futurism etc. that emerged before and after WWI as well as abstract expressionism, pop art, minimal art, etc. that came to the fore after WWII. 
concrete scenes and images? Perhaps Picasso thought that no representative scenes could express both the artist's anger and the heinous nature of crimes. (Li and Cauvel 2006, 153)

In addition, argues $\mathrm{Li}$, representational images are not able to express meanings that lie in deeper structures. In primitive art, the development from representation (mural paintings in caves) to expression (abstract decorations) often deepened the mystical colouring and sense of terror. The same phenomenon occurs in modern art. As Paul Klee said, the more terrible the world, the more abstract the form (ibid.).

During the transformation from concrete representations to abstract expression, the content conveyed in art becomes more and more complex. The content of emotion, imagination, and understanding expressed in abstraction is more profound and complicated than that expressed in representation. For Li, abstract art enriches and develops the aesthetic experience precisely because it opens up new forms of aesthetic experience and awareness that are the result of specific historical processes constituting a new psycho-emotional structures of human beings.

In modern art, abstract images reveal (or express) deep layers of the human psyche, especially the importance of human unconsciousness and the problem of (suppressed) sexual desires which were brought out by Freud's theory of psychoanalysis. The consciousness of death brought about by existentialism emphasized the awareness of the individual as the subject; Dadaism denied the meaning of art, beauty and aesthetics precisely in order to provoke the existing socio-political attitude towards the value of human beings and their creativity as such. These and many others artistic and philosophical currents that emerged in the 20th century influenced and shaped Western art in accordance with new reflections on individuality and on the relation between individuals and society. Hence, they represented a critical evaluation of the prevailing ethics and tradition.

For Li, the value and importance of modern abstract art lies in its reflection of the position of modern people as well as in its critique of the socio-political and economic conditions of the 20th century. Through such an abstract presentation and reflection of modern world, the aesthetic experience of human beings necessarily developed significantly as it gained more complex and profound dimensions.

For Li Zehou, art is the sedimentation of life. Therefore, the development of art and aesthetic awareness leak new sedimentations in the human psycho-emotional construction. In this dynamic process of change, the aesthetic experience of human life and that of artworks, become naturally endowed with new meanings. According to $\mathrm{Li}$, this development is beautiful because it enriches us and gives us new vital potentials, despite all the objective difficulties. 
Hence, Li's attitude towards new developments in aesthetics and society is very progressive and open to multi-layered contents that are brought about in these processes. In contrast to $\mathrm{Li}, \mathrm{Xu}$ Fuguan represents quite the opposite view. $\mathrm{Xu}$ was one of the first Chinese scholars who made a thorough comparative research on Chinese and Western art and aesthetics in the middle of the 1960s. Li Zehou deeply admired $\mathrm{Xu}$ for his pioneering work and frequently mentioned and quoted him in his works on aesthetics. Although Xu was a great admirer of traditional or classical Chinese and Western art, he had a great aversion towards modern abstract art. In the next section, I will present his understanding of modern Western abstract art which will illuminate some fundamental differences between his views and Li Zehou's comprehension of modern art and society.

\section{Xu Fuguan's Understanding and Attitude towards Modern Art}

$\mathrm{Xu}$ Fuguan ${ }^{5}$ views on modern art were published in the form of essays written mainly before he published his main work on Chinese art and aesthetics, The Spirit of Chinese Art, in 1966. It is important to mention that $\mathrm{Xu}$ admired traditional Chinese art and aesthetics immensely, therefore he felt an urge to write at length about its history, development and central aesthetic concepts. After he came across modern (or abstract) art while living in Japan, his compulsion to bring forward the richness and the profound value of classical Chinese art became even more pressing. As Su San Lee $(1998,318)$ pointed out, Xu's inspiration for writing The Spirit of Chinese Art was born after he visited Tokyo in 1960, where on the one hand he was overwhelmed by Japan's progressive economic and technological development, but on the other he was horrified by the popularity of modern Western art in which, as we will see, he not only beheld the destruction of art itself, but even the destruction of humanity. The popularity of modern Western art was also spreading among Taiwanese intellectual and artistic circles, and $\mathrm{Xu}$ was afraid that in their search for a new identity the Taiwanese youth would unreflectively and uncritically adopt this newly emerged art and completely do away with Chinese traditional culture and its artistic heritage. In his view, this new Taiwanese identity should be founded on a creative fusion of Chinese aesthetic tradition with certain elements deriving from modern Euro-American and Japanese cultures. ${ }^{6}$

5 Xu Fuguan (1904-1981) is one of the main representatives of the second generation of Modern Confucians who worked and lived in Taiwan and in Hong Kong after 1949 (Rošker 2019, 250).

6 Xu's fear that Taiwanese artists will adopt the Western worldview was also linked to the fact that Taiwanese youth did not perceive themselves as members of a concrete (i.e. Taiwanese) society. Besides, in the White Terror period most of the young Taiwanese were apolitical. In the 1960s, the young artistic, literary and intellectual circles found inspiration in Western literature and philosophy, in particular in the works of Kafka, Sartre, Camus and Nietzsche, along with others which became the true cultural heroes of desperate Taiwanese youth. In aesthetic circles, students of art quickly 
For $\mathrm{Xu}$, the elementary function of traditional art lies in a representation and integration of ethics, morality and the freedom of the human spirit. In this regard, Xu Fuguan's and Li Zehou's axiological aesthetics are equally rooted in a fusion of Confucian and Daoist philosophy. Although Xu deeply valued the Confucian notion of art as an educational tool for self-cultivation, and as the function of moulding and balancing human emotions that enabled humans to discover moral subjectivity, he nevertheless emphasized that the Zhuangzian attitude towards life is aesthetic in itself. Xu exposed Zhuangzi's aesthetic notions such as relativism, integral subjectivity, liberation of the Self through the methods of fasting of the mind (xinzhai 心齋) and sitting in forgetfulness (zuowang 坐忘), in order to show that the tendency of pursuing human liberation was something that existed in Chinese philosophical and artistic tradition long before its emergence modern Western art.

\section{Modern Art as the Symbol of Destruction of Humanity: An Analysis of Five Essays}

In this section, I will introduce Xu's assessment of modern or abstract art through the lens of five essays that were all published in the scope of $A \mathrm{Col}-$ lection of the Existing Essays of Xu Fuguan and Selected Essays of Xu Fuguan in 1980. However, most of the essays in which he elaborated upon this kind of art were written and published independently during the early 1960s. Through his writing it becomes clear that $\mathrm{Xu}$ was not only a traditionalist and conservative, but also that he quite severely neglected the importance of the origins of modern Western art, its ideational development and its socio-political backgrounds. The five essays discussed below elaborate on different aspects of modern art and Western culture, leading from simple historical descriptions to severe critiques of their "destructive" elements.

In his essay The Problem of the Eternity of Modern Art (Xiandai yishu de yonghengxing wenti 現代藝術的永恆性問題) written in 1965 (Xu 1980d), Xu pointed out that the spiritual background and characteristics of modern art derive from despair regarding the present era. Because of such despair, individuals sought to cut off all their ties to society and nature and lock themselves into their unconsciousness, expressing thereby either their supressed libido or their feelings of isolation and darkness. As regards the historical development of art itself and its pursuit of new forms, these are just secondary factors. Therefore, $\mathrm{Xu}$ pointed out

adopted abstract art. The members of these circles perceived themselves as representatives of a modern elite that was stuck in a conservative and backward society. The sense of alienation, which is one of the central features of modernism, coincided in this regard with the mindset of young Taiwanese writers and painters (Lee 1998,318). 
that modern art is but a transitional phenomenon in the development of art. This kind of art can hence be seen as an expression of a historical trauma, but it can by no means imply the eternity of $\operatorname{art}^{7}$ (Xu 1980d, 268).

In his essay Inhumane Art and Literature (Feirende yishu yu wenxue 非人的㙯術 與文學), written in 1961 (Xu 1980a), Xu argues that abstraction departs from nature and the surreal departs from human life and society. The core issue of abstraction and surrealism was WWII, and both movements completely disintegrated and crushed the previous traditions and ideas in art. Art is not beautiful anymore, it is not alive and is not a part of the spirit. They initiated the idea that art is stupid, bad, and purposely insane. Through the whole chaos and darkness of a revolt against nature, they want to establish a new realm. Painters and poets who concentrated on the spirit and life belong to the past, but abstractionists and surrealists think that art is a collection of sporadic, everyday objects. In their view, parrots and similar natural creatures were able to create art, and combs, pieces of paper, nails and stamps could be taken as material for artistic creations. $\mathrm{Xu}$ claimed that the attitude of modern art and literature towards tradition represented a thorough revolution. He believed that his analysis clearly showed that such art is merely an expression of the infinite depression of the era within the century of nihilism. Because its main source is despair and terror with regard to reality, modern art would necessarily lead to the destruction of humanity. In this way, modern artists would complete the fate of their era (ibid., 212-14).

In the same year, Xu published an essay entitled Modern Art's Revolt against $\mathrm{Na-}$ ture (Xiandai yishu dui ziran de panni 現代藝術對自然的叛逆) (Xu 1980e), beginning with the foreword, where he emphasized that in ancient China people saw themselves as arising from the same source as all the things around them. Hence, there existed mutual harmonious loving relation between human beings and nature. This idyllic foreword is followed by a severe critique of the modern age and modern art, in which Xu Fuguan argued that the latter left both human beings and nature behind. Actually, it was against nature itself. In Xu's view, this was inhuman. For him, abstract and surrealistic art were basically the same, for through their forms they both express chaos and irrationalism, deforming thereby human beings, society and nature. He believed that the ideological background of surrealistic art could be found in Freudian psychoanalysis, and the ideational background of abstract art in the abstraction and elimination of human feelings. Hence, in his view art which departs from nature also necessarily departs from people (ibid., 249-52).

$\mathrm{Xu}$ Fuguan declared that an artistic image without the image of nature is a symbol

7 For $\mathrm{Xu}$, the eternity of art is found in mutual relationship between the subject (artist) and the object (nature and society) (Xu 1980d, 268, 271). 
of destruction and denial of art itself. He did not promote realism and naturalism as the appropriate art forms, for art is neither completely subjective nor completely objective, but a transfer of the artist's spirit through an objective image. Nevertheless, he emphasized the importance of "depicting nature" in order to limit the tendency to excessive expression of individuality in modern art. He believed that nature was the main theme of both traditional Chinese and Western art since the Renaissance (Xu 1980e, 249-52).

For $\mathrm{Xu}$, nature could not be equated with the objective world as such, which includes both natural objects and the objects created by man. Instead, it was a wild, untamed landscape where one was liberated from social pressures, and thus able to feel communion with all creatures (Lee 1998, 331).

In an essay entitled The Signal of Dadaist Era (Dadazhuyi de shidai xinhao 達達主 義的時代信號) written in the same year (Xu 1980b), Xu discussed the Dadaist art movement and quoted from the Dada Manifesto the main goal and content of the movement, emphasizing its negation and revolt against art as such, society, ethics, and law. He further explained his view on the movement and defined it as a form of destructive mischief that reflects the background of modern circumstances, but is unable to bear any fruit. He claimed that even though the origin of this movement was connected to the revolt of spirit and individual temperament, the most important feature that led to it was actually the fact that, since the Renaissance, European thought was defined by the contradiction between society and culture on the one hand, and by the opposition between mechanistic civilization and humanism on the other. This phenomenon became even more obvious after WWI, when people felt that (Western) civilization was moving straight to its own suicide.

He argued that people lost their way out of this sense of terror, destabilization, and depression. Hence, weak-willed people saw no other way out than through the destruction of reality and the history from which it emerged. For Xu, Freudian psychoanalysis and the natural sciences encircled this callous atmosphere and encouraged these tendencies. Further in the text, $\mathrm{Xu}$ argued that Dadaism is the expansion of surrealism and abstractionism, while Sartre's existentialism as well as logical positivism are in their essence a kind of profound Dadaism. For Xu, the spirit of Dadaism is the inevitable emergence of the spirit of Western civilization in the present time. He concluded this essay with the rhetorical question: "Where to is the present era actually leading us" (ibid., 241-44).

In the essay The Goal of Modern Art (Xiandai yishu de guiqu 現代㙯術的歸趨) written in 1961 (Xu 1980c), Xu is similarly wondering where the abstract art of modern times will lead to. He believes that in the eyes of modern artists anyone asking that question is considered to be ignorant, lacking knowledge on true art, or even as someone who want to destroy it. Xu argues that the crucial aim of modern 
art is to be found in the image of destruction; for modern artists, the true artistic image should arise from objective nature, and therefore their so-called abstraction completely eradicates the artistic images of nature. In Xu's view the image is the life of art, so he wonders why modern artists want to destroy it. Although artistic images come from nature, the images on the paintings actually contain the emotions and individuality of the artists. Therefore they represent the crystallization of the fusion of object and subject. For $\mathrm{Xu}$, the image of an artwork is not imitation, but rather a sort of creation. The creation of art is unlimited like the universe, but modern art, which is using abstraction to destroy the image, disregards the fusion of new elements with the old tradition, and eliminates the significance of art. The second characteristic of modern art is for him its anti-rationalism. It does not recognize the laws of science and the natural order, and therefore it also opposes morality and culture. Modern artists excavate a hidden consciousness of chaos and darkness. They consider reason as hypocritical and not as a part of the human character, and they cannot recognize the value-system inherent in tradition and in social reality. Instead, they emphasize the need to overthrow tradition and humanism. In this aspect, they can be compared to communist materialism. The only difference between them lies in the fact that the communists still recognize objective laws and aim to construct a bright new future, whereas modern artists are a profoundly negative and chaotic group of people. They refuse the past and the future and are stuck in gloomy darkness. If this destructive work of modern surrealistic art would be accomplished, where would it actually lead people to? He concludes the essay with the statement: "They don't have anywhere to go and will only open up a path for communism” (Xu 1980c, 215-17).

With this essay, $\mathrm{Xu}$ gained quite a number of opponents in art circles, since he did not consider the fact that under the White Terror in Taiwan, any denotation of communist tendencies was severely punished, besides he was not aware that there were quite a few young painters in Taiwan who experimented with abstract expressionism. The young painter Liu Gongsong ${ }^{8}$ responded harshly to Xu's essay and this was published in his book The Path of Chinese Modern Painting (Zhongguo xiandaibua de lu 中國現代畫的路) in 1965. Liu succeeded in convincing the public of the importance of modern art, and of the fact that it was "resistant" to communist manipulations, since it symbolized the individualistic creativity of the so-called free world (Lee 1998, 313).

In this essay, Liu Guosong also responded to Xu's attitude to Dadaism and showed that $\mathrm{Xu}$ more obviously did not know the differences between particular currents of Western art, since he often mixed up or equated Dadaism with surrealism and abstractionism. Besides, the slaughter of WWI led the Dadaist movement to a

8 Liu Guosong is the first and most important representative of modernist and abstract Chinese painting in Taiwan, and also the leading figure in Taiwan's avant-garde circles. 
derogative scepticism towards art and all of Western culture; in contrast, surrealists and abstractionists still sought to develop new forms of art in order to create an artistic world that could coincide with the natural world. Liu Guosong argued that $\mathrm{Xu}$ misinterpreted Japanese sources on abstract Western painting, Dadaism and other art movements, and that $\mathrm{Xu}$ was incapable of understanding abstract paintings (Lee 998, 313). Nevertheless, Liu admitted that Xu correctly understood Dadaism as an artistic direction which mocks aesthetics, aesthetic taste and meaning, and indulges primarily to the expression of the human sub- and unconsciousness (Liu 1965, 157-76).

It is important to see that although Xu recognized the fundamental issues brought about by Dadaism, as Liu pointed out, he completely misunderstood the actual reasons for its intervention in Western society. The Dadaist negation of the abovementioned features lies precisely in their critique of the socio-political abolishment of the value of human beings, humanness and humanistic values. The existence and survival of art in such world is for them impossible.

Xu Fuguan's antipathy towards modern Western art was based on his belief that it radically opposed the moral consciousness of human nature and any form of civilized life. Modern art eliminated human reason and therefore brought out the manifestation of the obscure and absurd. For $\mathrm{Xu}$, contemporary artists did not recognize the rationality of human nature, nor the system of values, which are both the foundations of any tradition, reality and culture as such. They purposively eliminate all these basic features of humanity.

$\mathrm{Xu}$ Fuguan's rejection of modern abstract art is based on his view that it denied the organic and interdependent connection between the individual, society and culture, which results in a feeling of alienation, solitude, and sadness. Therefore, for $\mathrm{Xu}$, the problem of modern Western culture and art is that they are antisocial and anti-cultural (Huang 2019, 142-44). According to Huang (ibid.), what Xu Fuguan emphasized in his opposition to modern art is the "individualist mentality" presumably existing in modern Western art and culture. For $\mathrm{Xu}$, the individual who manifests him- or herself in contemporary Western art and culture always exists outside of cultural, traditional, interpersonal and social contexts. Among other issues, this assumption is doubtless also reflected in Xu's ethical thought.

\section{Conclusion}

Although Li Zehou and Xu Fuguan share the view that the profound and rich heritage of traditional Chinese aesthetics is based on the fusion of Confucian and Daoist philosophy, they greatly differ in their particular understandings of modern abstract art and aesthetics. Because they both proceed from the viewpoint that 
ethics cannot be separated from aesthetics, this difference also has wide-ranging implications for their respective systems of ethical thought.

For Li Zehou, the development from classical and representational art to abstract art is endowed with a new aesthetic experience which brings forward deeper and more profound developments in the human psycho-emotional structure. The sedimentation of complex intellectual and emotional experiences brought about by the new aesthetics of modern abstract art results in an advancement of human aesthetic faculties. The profoundness of modern abstract art is for $\mathrm{Li}$ also a reflection of economic and socio-political circumstances, which reveal the unique position of human beings in creating new conditions for human life in modern societies. The advance of modern abstract art and aesthetic experience therefore becomes endowed with political connotations which enable human beings to engage more intensively with specific conditions of a given reality. In his analyses of modern abstract art, Li thoroughly follows the historical conditions which lead to its emergence and sees it as a constructive and creative response to the difficult situation Western culture was facing in the early 20th century.

In contrast to such views, $\mathrm{Xu}$ Fuguan sees modern abstract art as an occurrence of hideous artistic forms without any aesthetic value and content. Besides, for $\mathrm{Xu}$, abstract art induces or even supports the socio-political situation Western society was facing at that time. Although he emphasizes the collective trauma and hopelessness of after both the First and Second World Wars, which were obviously reflected in modern art, he still blames such art for its negation of traditional values and culture. This ambiguous and ambivalent position towards modern abstract art and society reveals his lack of knowledge in the field of Western aesthetics.

Li Zehou's approach to human development in arts, aesthetics and society is hence progressive and open to new human experiences, while Xu Fuguan's attitude could be seen as regressive and even nihilistic. This becomes even more problematic if we consider the fact that the philosophical current of Modern Confucianism, to which $\mathrm{Xu}$ belonged, has widely been regarded as a progressive in its attempt to establish a fruitful dialogue with Western philosophy and culture. Considering the inseparable nature of ethical and aesthetic treatises in Chinese discourses, the paper has shown a profound axiological difference between the two scholars, for it illuminates the manifold reasons behind the fact that, in essence, Xu's theory is essentially neoconservative, while Li's ethics and moral philosophy are permeated with a much more positive and open-minded spirit, which is-inter alia-reflected in his cosmopolitan understanding of modern art. 


\section{References}

Bruya, Brian. 2003. "Li Zehou's Aesthetic as a Marxist Philosophy of Freedom." Dialogue and Universalism 11-12: 163-96. Accessed June 1, 2017. https:// philarchive.org/archive/BRULZA.

Cauvel, Jane. 1999. “The Transformative Power of Art: Li Zehou's Aesthetic Theory." Philosophy East and West 49 2: 150-73.

Chan, Sylvia. 2003. "Li Zehou and New Confucianism." In New Confucianism: A Critical Examination, edited by John Makeham, 105-28. New York: Palgrave Macmillan.

Woei, Lien Chong. 1999. "Kant and Marx in Post-Mao China: The Intellectual Path of Li Zehou." PhD diss., Amsterdam.

Huang, Chun Chieh. 2019. Xu Fuguan and his Thought in the Context of East Asian Confucianisms. Transleted by Diana Arghirescu. Honolulu: University of Hawai'i Press.

Lee, Su San. 1998. "Xu Fuguan and New Confucianism in Taiwan (1949-1969): A Cultural History of the Exile Generation." PhD diss., Brown University.

Li, Zehou. 2003. Meixue san shu 美學三書 (Three books on aesthetics). Tianjin: Tianjin shehui kexue yuan chubanshe.

Li, Zehou, and Cauvel, Jane. 2006. Four Essays on Aesthetics, toward Global View. Oxford: Lexington books.

Liu, Guosong. 1965. Zhongguo xiandaihua de lu 中國現代畫的路 (The Path of Chinese Modern Painting). Taiwan: Wenxing shudian.

Rošker, Jana S. 2006. Iskanje poti: Spoznavna teorija v kitajski tradiciji, drugi delZaton tradicije in obdobje moderne. Ljubljana: Razprave, Filozofska fakulteta.

Rošker, Jana S. 2019a. Following His Own Path: Li Zehou and Contemporary Chinese Philosophy. New York: Suny Press.

Rošker, Jana S. 2019b. "Filozofija na Tajvanu: nadaljevanje tradicije ali ustvarjanje novih teoretskih paradigem? (Philosophy in Taiwan: The Continuation of Tradition and the Creation of New Theoretical Paradigms)." Asian Studies 7 (2): 247-68.

Xu, Fuguan. 1980a. “Feirende yishu yu wenxue 非人的藝術與文學 (Inhumane Art and Literature).” In Xu Fuguan wencun 徐復觀文存 (A Collection of the Existing Essays of Xu Fuguan), edited by Ding Wenzhi, 212-14. Taiwan: Xuesheng shuju.

. 1980b. “Dadazhuyi de shidai xinhao 達達主義的時代信號 (The Signal of Dadaist Era).” In Xu Fuguan wenlu xuancui 徐復觀文錄選粹 (Selected Essays of Xu Fuguan), edited by Yang Yunlong, 241-44. Taiwan: Xuesheng shuju.

. 1980c. "Xiandai yishu de guiqu 現代藝術的歸趨 (The Goal of Modern Art).”In Xu Fuguan wencun 徐復觀文存 (A Collection of the Existing Essays of Xu Fuguan), edited by Ding Wenzhi, 215-17. Taiwan: Xuesheng shuju. 
—. 1980d. “Xiandai yishu de yonghengxing wenti 現代藝術的永恆性問題 (The Problem of the Eternity of Modern Art).” In Xu Fuguan wenlu xuancui 徐復觀文錄選粹 (Selected Essays of Xu Fuguan), edited by Yang Yunlong, 268-72. Taiwan: Xuesheng shuju.

- 1980e. “Xiandai yishu dui ziran de panni 現代藝術對自然的叛逆 (Modern Art's Revolt against Nature).” In Xu Fuguan wencun 徐復觀文存 ( $A$ Collection of the Existing Essays of Xu Fuguan), edited by Ding Wenzhi, 249-52. Taiwan: Xuesheng shuju.

Welsch, Wolfgang. 2014. "Schiller Revisited: Beauty is Freedom in Appearance" - Aesthetic as a Challenge to the Modern Way of Thinking." Contemporary Aesthetics 12. http://hdl.handle.net/2027/spo.7523862.0012.016. 